\title{
Effect of Foliar Application of Urea on Growth and Yield of Short Durative Lentil Variety (BARI Masur-9)
}

\author{
Md. Shahriar Kobir ${ }^{1}$, Md. Harun-Or-Rashid ${ }^{2} \&$ Md. Hafijur Rahman ${ }^{1}$ \\ ${ }^{1}$ Bangladesh Agricultural Research Institute, Bangladesh \\ ${ }^{2}$ International Maize and Wheat Improvement Center (CIMMYT), Bangladesh Office, Bangladesh \\ Correspondence: Md. Shahriar Kobir, Bangladesh Agricultural Research Institute, Bangladesh. E-mail: \\ shahriar1302027@gmail.com
}

Received: June 26, 2020 Accepted: July 17, 2020 Online Published: July 20, 2020

\begin{abstract}
An experiment was conducted at Regional Agricultural Research Station, Jashore, Bangladesh during rabi season of (2019-2020) to evaluate the effect of foliar application of urea on growth and yield of short durative lentil variety (BARI Masur-9). The experiment was conducted in split plot design with three replications where time of urea spraying, $\mathrm{P} 1=$ at branching stage, $\mathrm{P} 2=$ at pod initiation stage were distributed in main plots and doses of urea spraying $\mathrm{T} 1=$ application of $100 \%$ recommended fertilizers as basal except urea, $\mathrm{T} 2=$ application of $100 \%$ recommended fertilizers as basal, T3= application of $75 \%$ of urea with $100 \%$ of other fertilizers as basal and rest of the $25 \%$ of urea by spraying, T4= application of $25 \%$ of urea with $100 \%$ of other fertilizers as basal and rest of the $75 \%$ of urea by spraying, T5= application of $50 \%$ of urea with $100 \%$ of other fertilizers as basal and rest of the $50 \%$ of urea by spraying were distributed in sub plots. The highest plant height, number of pods per plant were obtained from application of $75 \%$ of urea with $100 \%$ of other fertilizers as basal and rest of the $25 \%$ of urea spraying at pod initiation stage. The highest seed yield was also found from application of $75 \%$ of urea with $100 \%$ of other fertilizers as basal and rest of the $25 \%$ of urea spraying at pod initiation stage followed by application of $100 \%$ recommended fertilizers as basal and application of $50 \%$ of urea with $100 \%$ of other fertilizers as basal and rest of the $50 \%$ of urea by spraying at branching stage. Plant height, pods per plant and days to maturity showed positive correlation with seed yield. On the other hand days to flower and plants per $\mathrm{m}^{2}$ has no linear relationship with seed yield. The highest marginal benefit cost ratio (3.29) was recorded from application of $75 \%$ of urea with $100 \%$ of other fertilizers as basal and rest of the $25 \%$ of urea by spraying at pod initiation stage. So based on findings to increase the yield potential of BARI Masur-9 foliar application of urea may be a tool and hence application of $75 \%$ of urea with $100 \%$ of other fertilizers as basal and rest of the $25 \%$ of urea by spraying at pod initiation stage may be consider as the best treatment.
\end{abstract}

Keyword: foliar urea spray, lentil, pulses, BARI Masur-9

\section{Introduction}

Besides the main crops pulses also play a major role to minimize the human food needs. Lentil (Locally Masur) is an important food source for the people especially in the subcontinent (Hamayun et al., 2011). Pulses are important source of protein particularly for the poor people and provides nutritional security (Das and Jana, 2015). In the year 2018-19, Bangladesh produced about 0.17 million tons of lentil from its 0.14 million hectares land (BBS, 2019) and average productivity was only 1.3 tons $^{-1}$ (AIS, 2020). BARI Masur-9 is a recent released variety of lentil in Bangladesh by Bangladesh Agricultural Research Institute which is a short durative variety whose average life cycle is about 90 days. A huge number of cultivable land became remain fallow in between transplanted Aman and Boro rice in Bangladesh but after releasing this variety this problem may be solved somehow (Azad et al., 2019). But as this varieties average yield (1.19-1.52 tha $\left.\mathrm{A}^{-1}\right)$ is very much lower than the other on season varieties, adaptation and acceptance of this variety to the farmer's is not satisfactory. Moreover the area of lentil cultivation in the country is decreasing day by day because of it's poor yield (Salam et al., 2019). In addition farmers are growing lentil under resource constraints situation. The major constraints are being poor crop establishment and drought in the later stages of crop growthand it affects the productivity. Farmers are very much habituated to apply basal dose of fertilizer in lentil, which ultimately results in poor yield (Ram and Punia, 2018). So time to time measures have to apply to increase the yield of released variety. 
Foliar application is regarded as a preferred solution when quick supply of nutrients is hindered or the soil conditions are not conducive for the absorption of nutrients (Salisbury and Ross, 1985). Pods and seeds development are mainly dependent on nitrogen and carbon accumulation, prior to podding (Davies et al., 2000) but root fails to absorb nitrogen from dry soil. This technique helps the nutrients to reach the site of food synthesis directly, leading no wastage and quick supply of food and thereby reduce the requirement of fertilizers. Photosynthesis gets reduced due to depletion of nitrogen in leaves, senescence starts earlier in lentil before completion of maturity which break the source to sink relation, thereby the yield reduces. Foliar nutrition can hasten the growth of a crop by delaying senescence. The positive effect of supplying lentil with supplementary nitrogen was found to have beneficial effects on enhancing growth and increasing seed yield by quick supply of nitrogen (Das and Jana, 2015).

Therefore foliar application of water soluble fertilizers like urea as supplementary nitrogen or a balanced dose of nutrients may be a very good option to increase the yield of BARI Masur-9 as well as other cultivars.

\section{Materials and Methods}

The experiment was conducted at Regional Agricultural Research Station, Jashore, Bangladesh during Rabi 20192020 to investigate the "effect of foliar application of urea on growth and yield of short durative lentil variety (BARI Masur-9)". The methods and materials that had been used in the experiment will be described in this chapter:

Experimental Site: The site where the experiment has conducted is located on $23^{\circ} 18^{\prime}$ latitude and $89^{\circ} 18^{\prime}$ longitude with an elevation of $19 \mathrm{~m}$ from sea level (Kobir et al., 2020). The experimental site is undergoes the Agro Ecological Zone (AEZ-11) namely 'High Ganges River Floodplain' (BBS, 2019).

Soil: Textural class of the experimental site's soil was sandy clay loam in nature and general soil type of the site is 'Calcareous Dark Grey Floodplain' soil. The soil contain 1.7\% organic matter and the soil is slightly alkaline in reaction (Table 1).

Table 1. Particle size distribution, textural class, bulk density, $\mathrm{pH}$ and soil organic matter of initial soil of the experimental field

\begin{tabular}{|c|c|c|c|c|c|c|c|}
\hline \multirow{2}{*}{$\begin{array}{l}\text { Soil depth } \\
\text { (cm) }\end{array}$} & \multicolumn{3}{|c|}{ Particle size distribution } & \multirow{2}{*}{ Textural class } & \multirow{2}{*}{$\begin{array}{l}\text { Bulk density } \\
\qquad\left(\mathrm{g} \mathrm{cm}^{-3}\right)\end{array}$} & \multirow{2}{*}{$\mathrm{pH}$} & \multirow{2}{*}{ SOM $(\%)$} \\
\hline & Sand $\%$ & Silt $\%$ & Clay\% & & & & \\
\hline $0-15$ & 53.00 & 24.28 & 22.72 & Sandy clay loam & 1.42 & 7.6 & 1.7 \\
\hline
\end{tabular}

Source: Soil science division, Bangladesh Agricultural Research Institute

Climate: Annual average temperature of the experimental site is $15.4^{\circ} \mathrm{c}$ to $34.6^{\circ} \mathrm{c}$ and annual rainfall is $1537 \mathrm{~mm}$ (Wikipedia). The prevailed average temperature, average humidity and total rainfall during the operation of the experiment is showed in (Fig 1):

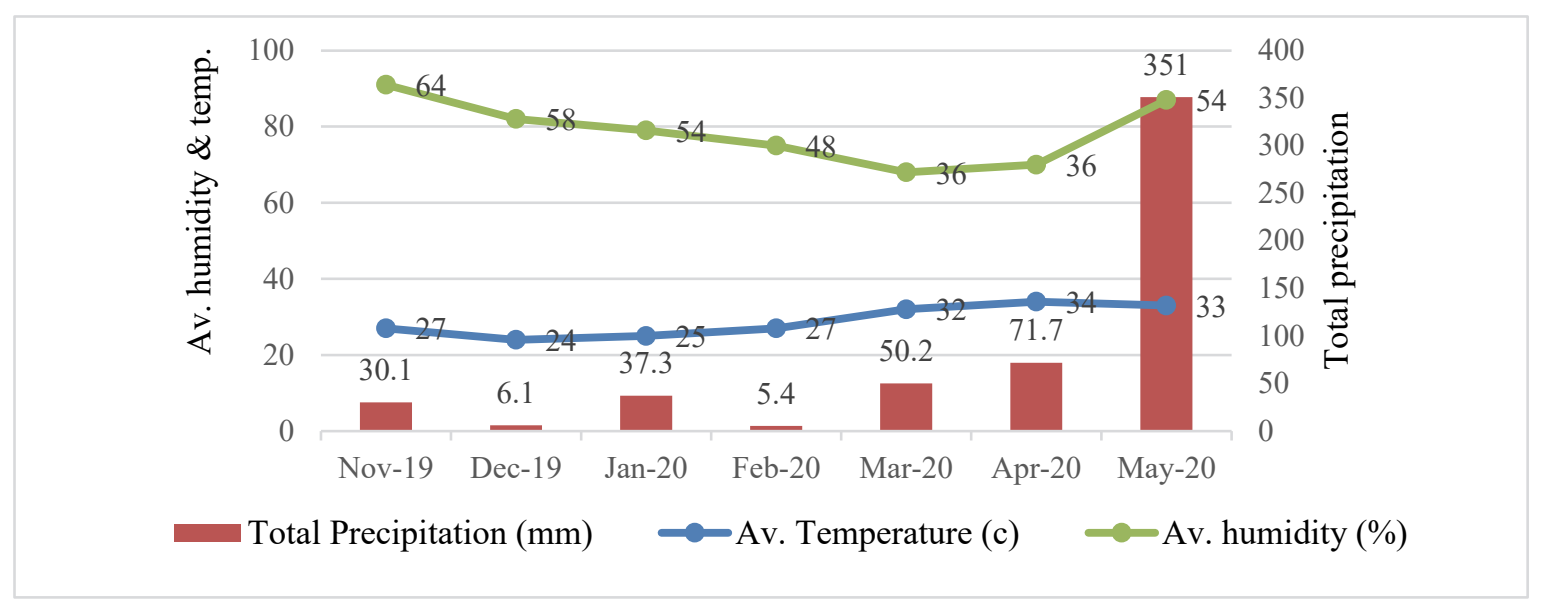

Figure 1. Weather data of Jashore from November 2019- May 2020 
Planting material: The planting material that had been used in this experiment was BARI Masur-9. BARI Masur9 is a short durative lentil variety that can be cultivated in the fallow period of between transplanted Aman and Boro rice. Seeds of the planting material was collected from pulses research centre, Ishurdi, Pabna. Average life cycle of this variety is 85-90 days, in addition this variety is tolerante to Stemphylium blight disease and average yield is 1.19-1.52 tha ${ }^{-1}$. The most special character of this cultivar is that it is Fe and Zn enriched in nature (Azad et al.,2019).

Experimental treatment: The experiment was conducted considering the following factors

\begin{tabular}{|c|c|c|}
\hline Factors & & Details of the treatments \\
\hline \multirow{2}{*}{$\begin{array}{l}\text { Factor A: Phases of } \\
\text { urea spraying }\end{array}$} & $\mathrm{P} 1$ & Urea spraying at branching stage \\
\hline & $\mathrm{P} 2$ & Urea spraying at pod initiation stage \\
\hline \multirow{5}{*}{$\begin{array}{l}\text { Factor B: Doses of } \\
\text { urea spraying }\end{array}$} & $\mathrm{T} 1$ & $\mathrm{~T} 1=$ application of $100 \%$ recommended fertilizers as basal except urea \\
\hline & $\mathrm{T} 2$ & $\mathrm{~T} 2=$ application of $100 \%$ recommended fertilizers as basal \\
\hline & T3 & $\begin{array}{l}\mathrm{T} 3=\text { application of } 75 \% \text { of urea with } 100 \% \text { of other fertilizers as } \\
\text { basal and rest of the } 25 \% \text { of urea by spraying }\end{array}$ \\
\hline & $\mathrm{T} 4$ & $\begin{array}{l}\mathrm{T} 4=\text { application of } 25 \% \text { of urea with } 100 \% \text { of other fertilizers as basal } \\
\text { and rest of the } 75 \% \text { of urea by spraying }\end{array}$ \\
\hline & T5 & $\begin{array}{l}\mathrm{T} 5=\text { application of } 50 \% \text { of urea with } 100 \% \text { of other fertilizers as basal } \\
\text { and rest of the } 50 \% \text { of urea by spraying }\end{array}$ \\
\hline
\end{tabular}

Experimental design and layout: The research was conducted in split plot design where various stages of urea spraying distributed in main plots and different doses of urea spraying distributed in sub plots. Thus total number of plot was $(2 * 5 * 3)=30$ and each plot size was $(1.5 * 4) \mathrm{m}^{2}=6 \mathrm{~m}^{2}$.

Crop husbandry: At first the land was ploughed three times by tractor drawn cultivator followed by rotavator till the soil appeared as fine tilth. Then collected seeds of BARI Masur-9 was treated with a fungicide Provax-200 WP@2.5 gkg-1 seed. Seeds were sown in continuous line sowing method@70-80 $\mathrm{kgha}^{-1}$ where line to line distance was $30 \mathrm{~cm}$. Fertilizers were applied as per the proposed treatments method and doses (Table 2).

Table 2. Different doses of urea spray as per proposed treatments

\begin{tabular}{ccccccc}
\hline $\begin{array}{c}\text { Treatmen } \\
\mathrm{t}\end{array}$ & $\begin{array}{c}\text { Urea basal } \\
\left(\mathrm{kgha}^{-1}\right)\end{array}$ & $\begin{array}{c}\text { Urea } \\
\text { spray } \\
\left(\mathrm{kgha}^{-1}\right)\end{array}$ & $\begin{array}{c}\text { TSP } \\
\left(\mathrm{kgha}^{-1}\right)\end{array}$ & $\begin{array}{c}\text { MOP } \\
\left(\mathrm{kgha}^{-1}\right)\end{array}$ & $\begin{array}{c}\text { Gypsum } \\
\left(\mathrm{kgha}^{-1}\right)\end{array}$ & $\begin{array}{c}\text { Boric acid } \\
\left(\mathrm{kgha}^{-1}\right)\end{array}$ \\
\hline $\mathrm{T} 1$ & 0 & 0 & 80 & 30 & 50 & 7 \\
T2 & 40 & 0 & 80 & 30 & 50 & 7 \\
T3 & 30 & 10 & 80 & 30 & 50 & 7 \\
T4 & 10 & 30 & 80 & 30 & 50 & 7 \\
T5 & 20 & 20 & 80 & 30 & 50 & 7 \\
\hline
\end{tabular}

Two times weeding was done at 30 days after sowing and 60 days after sowing, respectively. Crops were harvested at proper harvest maturity and harvested crops were sun dried for three days and then threshed on floor.

Collection of experimental data and analyzing statistically: Data of days to flower, days to maturity, plants per $\mathrm{m}^{2}$ at harvest, pods per plant at harvest, plant height at harvest and grain yield was collected from each plot and then collected data were converted to per hactre. Then the collected data were tabulized and a statistical software statistix-10 was used to calculate analysis of variance and means of the measured parameters were compared using LSD at alpha $=0.05$.

\section{Results}

Effect of different phases of urea spraying: Different phases of urea spraying showed significant variation among the parameters except plants per $\mathrm{m}^{2}$, pods per plant and yield (table 3). The highest days to flower (40), days to 
maturity (94), plant height $(32.93 \mathrm{~cm}$ ) was recorded from P1 (at branching stage), P2 (at pod initiation stage) and P2 (at pod initiation stage) phases respectively (Table 3). On the other hand the lowest days to flower (39), days to maturity (92) and plant height $(32.43 \mathrm{~cm}$ ) was recorded from P2 (at pod initiation stage), P1 (at branching stage) and P1 (at branching stage) phases, respectively (Table 03).

Table 3. Yield and yield contributing characters of lentil affected by different phases of spraying

\begin{tabular}{ccccccc}
\hline Phases & $\begin{array}{c}\text { Days to } \\
\text { flowering }\end{array}$ & Days to maturity & $\begin{array}{c}\text { Plant height } \\
(\mathrm{cm})\end{array}$ & $\begin{array}{c}\text { Plants } \mathrm{m}^{-2} \\
(\text { No. })\end{array}$ & $\begin{array}{c}\text { PodsPlant }^{-1} \\
\left(\text { No. }^{2}\right.\end{array}$ & $\begin{array}{c}\text { Yield } \\
\left(\mathrm{kgha}^{-1}\right)\end{array}$ \\
\hline P1 & 40 & 92 & 32.43 & 161 & 28 & 1326 \\
P2 & 39 & 94 & 32.93 & 161 & 30 & 1274 \\
\hline CV (\%) & 0.80 & 0.68 & 7.45 & 1.68 & 13.33 & 6.54 \\
LSD (0.05) & 0.49 & 0.99 & 3.82 & NS & NS & NS \\
\hline
\end{tabular}

$\mathrm{P} 1=$ at branching stage, $\mathrm{P} 2=$ at pod initiation stage

Effect of different doses of urea spraying: Different doses of urea showed significant variation among the parameters except plants per $\mathrm{m}^{2}$ (Table 4). The highest days to flower (40) were found from T3 (application of 75\% of urea with $100 \%$ of other fertilizers as basal and rest of the $25 \%$ of urea by spraying) treatment which is similar to T4 (application of $25 \%$ of urea with $100 \%$ of other fertilizers as basal and rest of the $75 \%$ of urea by spraying) and T5 (application of 50\% of urea with $100 \%$ of other fertilizers as basal and rest of the $50 \%$ of urea by spraying) treatments. On the other hand the lowest days to flower (39) were recorded from T1 (application of 100\% recommended fertilizers as basal except urea) and T2 (application of 100\% recommended fertilizers as basal) treatments. The highest (94) and the lowest (92) days to maturity was found from T5 (application of 50\% of urea with $100 \%$ of other fertilizers as basal and rest of the $50 \%$ of urea by spraying) and T1 (application of $100 \%$ recommended fertilizers as basal except urea) treatment respectively (Table 04). The highest plant height (34.75 $\mathrm{cm}$ ) was observed from T3 (application of 75\% of urea with $100 \%$ of other fertilizers as basal and rest of the $25 \%$ of urea by spraying) treatments and the lowest (28.33) from T5 (application of 50\% of urea with 100\% of other fertilizers as basal and rest of the $50 \%$ of urea by spraying) treatment. The highest pods per plant (34) was observed from T3 (application of 75\% of urea with 100\% of other fertilizers as basal and rest of the $25 \%$ of urea by spraying) treatments and the lowest (21) from T5 (application of 50\% of urea with 100\% of other fertilizers as basal and rest of the $50 \%$ of urea by spraying) treatment (Table 04$)$. The highest yield $\left(1517.3 \mathrm{kgha}^{-1}\right)$ was recorded from T3 (application of $75 \%$ of urea with $100 \%$ of other fertilizers as basal and rest of the $25 \%$ of urea by spraying) treatment followed by T2 (application of 100\% recommended fertilizers as basal) and T5 (application of 50\% of urea with $100 \%$ of other fertilizers as basal and rest of the $50 \%$ of urea by spraying) treatments (Table 04 ). On the other hand the lowest yield $\left(1160.8 \mathrm{kgha}^{-1}\right)$ was found from $\mathrm{T} 1$ (application of $100 \%$ recommended fertilizers as basal except urea) treatment (Table 4).

Table 4. Yield and yield contributing characters of lentil affected by different doses of urea spraying

\begin{tabular}{ccccccc}
\hline Treatments & Days to flowering & Days to maturity & $\begin{array}{c}\text { Plant height } \\
(\mathrm{cm})\end{array}$ & $\begin{array}{c}\text { Plants m } \\
(\text { No. })\end{array}$ & $\begin{array}{c}\text { PodsPlant } \\
(\text { No. })\end{array}$ & $\begin{array}{c}\text { Yield }^{-1} \\
\left(\mathrm{kgha}^{-1}\right)\end{array}$ \\
\hline T1 & 39 & 92 & 33.20 & 158 & 26 & 1160.8 \\
T2 & 39 & 93 & 33.16 & 160 & 32 & 1400.2 \\
T3 & 40 & 93 & 34.75 & 164 & 34 & 1517.3 \\
T4 & 40 & 93 & 33.96 & 160 & 30 & 1170.7 \\
T5 & 40 & 94 & 28.33 & 161 & 21 & 1252.0 \\
\hline CV (\%) & 0.95 & 0.75 & 10.84 & 3.96 & 14.34 & 7.22 \\
LSD (0.05) & 0.46 & 0.85 & 4.33 & NS & 5.01 & 114.85 \\
\hline
\end{tabular}

$\mathrm{T} 1=$ application of $100 \%$ recommended fertilizers as basal except urea, T2= application of $100 \%$ recommended fertilizers as basal, T3= application of $75 \%$ of urea with $100 \%$ of other fertilizers as basal and rest of the $25 \%$ of urea by spraying, T4= application of $25 \%$ of urea with $100 \%$ of other fertilizers as basal and rest of the $75 \%$ of 
urea by spraying, $\mathrm{T} 5=$ application of $50 \%$ of urea with $100 \%$ of other fertilizers as basal and rest of the $50 \%$ of urea by spraying.

Effect of different interactions: Interaction effect of different phases of urea spraying and different doses of urea spraying showed significant variation among the parameters except days to flower (Table 5). The highest plants per $\mathrm{m}^{2}(168)$ and the lowest (152) was found from P2T4 (application of $25 \%$ of urea with $100 \%$ of other fertilizers as basal and rest of the $75 \%$ of urea by spraying at pod initiation stage) and P1T4 (Basal application of $25 \%$ of the urea recommended dose + full dose of other fertilizers during final land preparation and rest of the $75 \%$ of urea recommended dose by spraying at branching stage ) interaction effect, respectively (Table 05 ). The highest days to maturity (95) was observed from P2T5 (application of 50\% of urea with $100 \%$ of other fertilizers as basal and rest of the $50 \%$ of urea by spraying at pod initiation stage) and P2T 4 (application of $25 \%$ of urea with $100 \%$ of other fertilizers as basal and rest of the $75 \%$ of urea by spraying at pod initiation stage) interaction effect which is statistically similar to P2T1 (application of 100\% recommended fertilizers as basal except urea), P2T2 (Basal application of $100 \%$ recommended fertilizers as basal) and P2T3 (application of $75 \%$ of urea with $100 \%$ of other fertilizers as basal and rest of the $25 \%$ of urea by spraying at pod initiation stage) interaction effect. On the other hand the lowest (91) days to maturity was observed from P1T1 (application of $100 \%$ recommended fertilizers as basal except urea) interaction which is statistically similar to P1T2 (application of $100 \%$ recommended fertilizers as basal), P1T3 (Basal application of $75 \%$ of the urea recommended dose + full dose of other fertilizers during final land preparation and rest of the $25 \%$ of urea recommended dose by spraying at branching stage) and P1T4 (application of $25 \%$ of urea with $100 \%$ of other fertilizers as basal and rest of the $75 \%$ of urea by spraying at branching stage) interaction effect (Table 05). The highest $(39 \mathrm{~cm})$ and the lowest $(23 \mathrm{~cm})$ plant height were observed from P2T3 (application of 75\% of urea with 100\% of other fertilizers as basal and rest of the $25 \%$ of urea by spraying at pod initiation stage) and P2T5 (application of 50\% of urea with $100 \%$ of other fertilizers as basal and rest of the $50 \%$ of urea by spraying at pod initiation stage) interaction effect respectively. The highest (38) and the lowest (21) pods per plant was recorded from P2T3 (application of $75 \%$ of urea with $100 \%$ of other fertilizers as basal and rest of the $25 \%$ of urea by spraying at pod initiation stage) and P2T5 (application of $50 \%$ of urea with $100 \%$ of other fertilizers as basal and rest of the $50 \%$ of urea by spraying at pod initiation stage) interaction effect respectively (Table 05 ). The highest yield $\left(1625.7 \mathrm{kgha}^{-1}\right.$ ) was observed from P2T3 (application of $75 \%$ of urea with $100 \%$ of other fertilizers as basal and rest of the $25 \%$ of urea by spraying at pod initiation stage) interaction effect followed by P1T5 (application of 50\% of urea with $100 \%$ of other fertilizers as basal and rest of the $50 \%$ of urea by spraying at branching stage), P1T3 (application of 75\% of urea with 100\% of other fertilizers as basal and rest of the $25 \%$ of urea by spraying at branching stage) and P2T2 (application of $100 \%$ recommended fertilizers as basal) interaction effect. On the other hand the lowest yield (1006.3 $\left.\mathrm{kgha}^{-1}\right)$ was observed from P2T4 (application of $25 \%$ of urea with $100 \%$ of other fertilizers as basal and rest of the $75 \%$ of urea by spraying at pod initiation stage) interaction effect (Table 05).

Table 5. Yield and yield contributing characters of lentil affected by different interaction

\begin{tabular}{|c|c|c|c|c|c|c|}
\hline Interactions & $\begin{array}{c}\text { Days to } \\
\text { flowering }\end{array}$ & $\begin{array}{l}\text { Days to } \\
\text { maturity }\end{array}$ & $\begin{array}{c}\text { Plant height } \\
(\mathrm{cm})\end{array}$ & $\begin{array}{c}\text { Plants } \mathrm{m}^{-2} \\
\text { (No.) }\end{array}$ & $\begin{array}{l}\text { PodsPlant }^{-1} \\
\text { (No.) }\end{array}$ & $\begin{array}{c}\text { Yield } \\
\left(\mathrm{kgha}^{-1}\right)\end{array}$ \\
\hline P1T1 & 39 & 91 & 33.20 & 156 & 25 & 1124.3 \\
\hline P1T2 & 40 & 91 & 29.00 & 161 & 32 & 1302 \\
\hline P1T3 & 40 & 92 & 30.50 & 165 & 29 & 1409 \\
\hline P1T4 & 40 & 92 & 35.80 & 152 & 30 & 1334.7 \\
\hline P1T5 & 40 & 92 & 33.67 & 167 & 21 & 1460.7 \\
\hline $\mathrm{P} 2 \mathrm{~T} 1$ & 39 & 94 & 33.20 & 159 & 28 & 1197.3 \\
\hline $\mathrm{P} 2 \mathrm{~T} 2$ & 39 & 94 & 37.33 & 159 & 32 & 1498.3 \\
\hline P2T3 & 39 & 94 & 39.00 & 162 & 38 & 1625.7 \\
\hline P2T4 & 39 & 95 & 32.13 & 168 & 30 & 1006.3 \\
\hline P2T5 & 40 & 95 & 23.00 & 155 & 21 & 1043.3 \\
\hline CV (\%) & 0.95 & 0.75 & 10.84 & 3.96 & 14.34 & 7.22 \\
\hline $\operatorname{LSD}(0.05)$ & 10.51 & NS & 6.43 & 3.91 & 8.28 & 184.42 \\
\hline
\end{tabular}

$\mathrm{P} 1=$ at branching stage, $\mathrm{P} 2=$ at pod initiation stage were distributed in main plots and doses of urea spraying, $\mathrm{T} 1=$ application of $100 \%$ recommended fertilizers as basal except urea, $\mathrm{T} 2=$ application of $100 \%$ recommended fertilizers as basal, $\mathrm{T} 3=$ application of $75 \%$ of urea with $100 \%$ of other fertilizers as basal and rest of the $25 \%$ of urea by spraying, T4= application of $25 \%$ of urea with $100 \%$ of other fertilizers as basal and rest of the $75 \%$ of 
urea by spraying, T5= application of $50 \%$ of urea with $100 \%$ of other fertilizers as basal and rest of the $50 \%$ of urea by spraying

Correlation co-efficient and regression equation: Plant height $(\mathrm{r}=0.65)$ showed strong positive correlation with grain yield (Fig 4), pods per plant $(\mathrm{r}=0.5)$ showed moderate positive correlation with grain yield (Fig 5 ), days to maturity $(\mathrm{r}=0.21)$ showed small positive correlation with grain yield (Fig 3). On the other hand days to flower and plants per $\mathrm{m}^{2}$ have non-linear relationship with grain yield (Fig 2, 6).

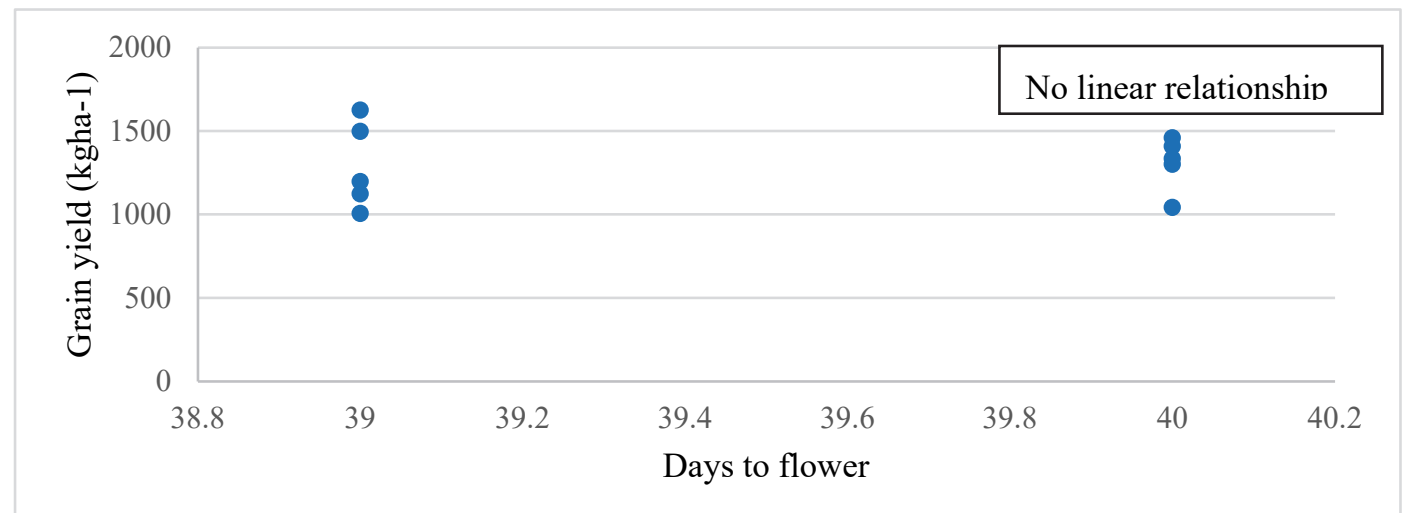

Figure 2. Correlation co-efficient of days to flower Vs Grain yield $\left(\mathrm{kgha}^{-1}\right)$

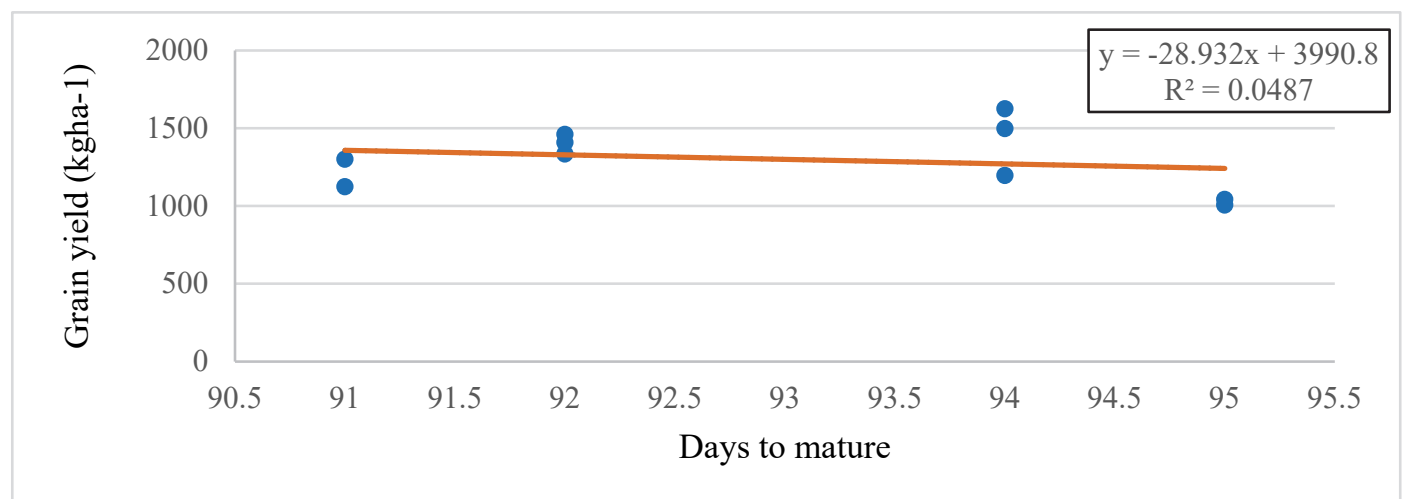

Figure 3. Correlation co-efficient of days to mature Vs Grain yield $\left(\mathrm{kgha}^{-1}\right)$

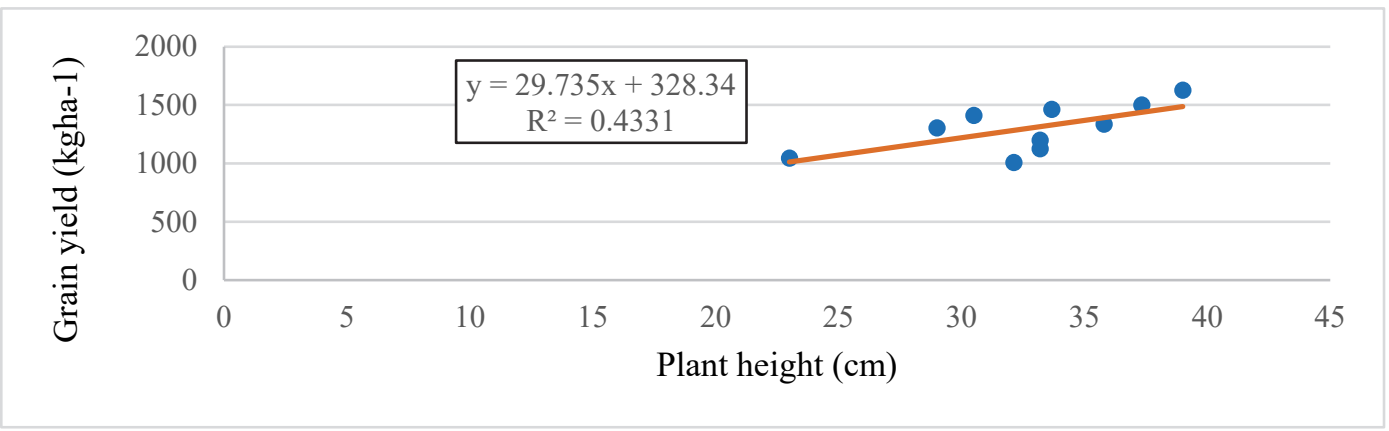

Figure 4. Correlation co-efficient of plant height $(\mathrm{cm})$ Vs Grain yield $\left(\mathrm{kgha}^{-1}\right)$ 


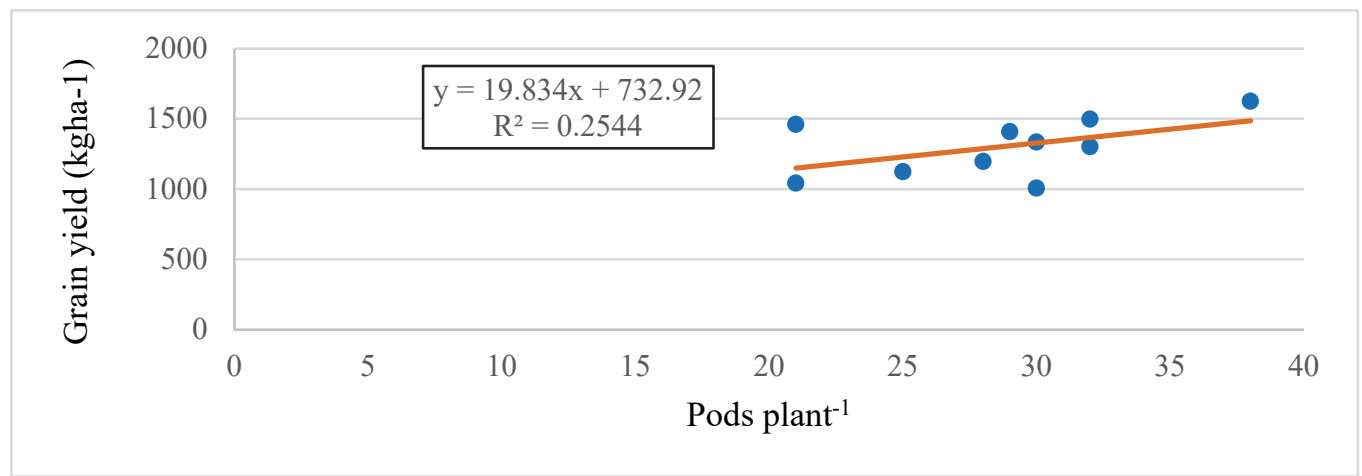

Figure 5. Correlation co-efficient of pods plant-1 Vs Grain yield (kgha-1)

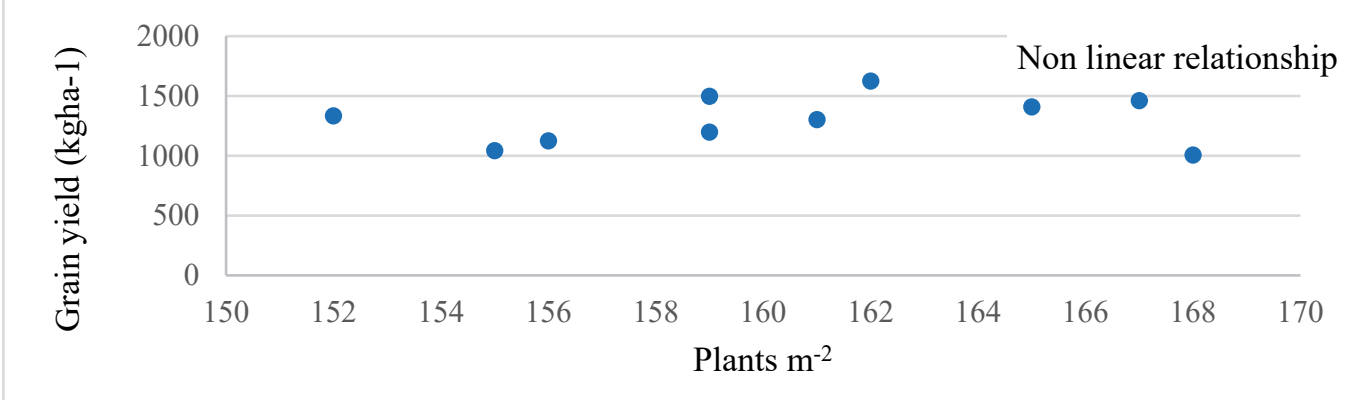

Figure 6. Correlation co-efficient of plants $\mathrm{m}^{-2}$ Vs Grain yield $\left(\mathrm{kgha}^{-1}\right)$

Economic analysis: The highest amount of grain yield $\left(1625.7 \mathrm{kgha}^{-1}\right)$, the highest additional yield over practising method $\left(225.7 \mathrm{~kg} \mathrm{ha}^{-1}\right)$, the highest additional return (11736.4 BDT ha' $\left.{ }^{-1}\right)$ as well as the highest marginal benefit cost ratio (3.29) was recorded from P2T3 (application of 75\% of urea with 100\% of other fertilizers as basal and rest of the $25 \%$ of urea by spraying at pod initiation stage) interaction effect (Table 6 ).

Table 6. Partial cost analysis of interactions for different time of urea spraying and different doses of urea spraying in lentil

\begin{tabular}{|c|c|c|c|c|c|c|c|}
\hline \multirow{2}{*}{$\begin{array}{c}\text { Interaction } \\
\quad \mathrm{s}\end{array}$} & \multirow{2}{*}{$\begin{array}{l}\text { Grain } \\
\text { yield }(\mathrm{kg} \\
\left.\mathrm{ha}^{-1}\right)\end{array}$} & \multirow{2}{*}{$\begin{array}{l}\text { Additional } \\
\text { Yield (kg ha- } \\
\text { 1) over } \\
\text { practising } \\
\text { method }\end{array}$} & \multirow{2}{*}{$\begin{array}{l}\text { Additional } \\
\text { Return } \\
\left(\text { BDT ha }^{-1}\right)\end{array}$} & \multicolumn{2}{|c|}{$\begin{array}{c}\text { Variable cost (BDT ha- } \\
1 \text { ) }\end{array}$} & \multirow{2}{*}{$\begin{array}{c}\text { Total } \\
\text { variable } \\
\text { cost }(\mathrm{BDT} \\
\left.\mathrm{ha}^{-1}\right)\end{array}$} & \multirow{2}{*}{$\begin{array}{l}\text { MBCR } \\
\text { (over } \\
\text { practising } \\
\text { method) }\end{array}$} \\
\hline & & & & $\begin{array}{c}\text { (Labour + } \\
\text { sprayer) }\end{array}$ & Urea & & \\
\hline P1T1 & 1124.3 & - & - & 0 & 0 & 0 & - \\
\hline P1T2 & 1302 & - & - & 0 & 560 & 560 & - \\
\hline P1T3 & 1409 & 107 & 5564 & 3000 & 560 & 3560 & 1.56 \\
\hline P1T4 & 1334.7 & 32.7 & 1700.4 & 3000 & 560 & 3560 & 0.47 \\
\hline P1T5 & 1460.7 & 158.7 & 8252.4 & 3000 & 560 & 3560 & 2.31 \\
\hline $\mathrm{P} 2 \mathrm{~T} 1$ & 1197.3 & - & - & 0 & 0 & 0 & - \\
\hline $\mathrm{P} 2 \mathrm{~T} 2$ & 1400 & - & - & 3000 & 560 & 3560 & - \\
\hline P2T3 & 1625.7 & 225.7 & 11736.4 & 3000 & 560 & 3560 & 3.29 \\
\hline P2T4 & 1006.3 & - & - & 3000 & 560 & 3560 & - \\
\hline $\mathrm{P} 2 \mathrm{~T} 5$ & 1043.3 & - & - & 3000 & 560 & 3560 & - \\
\hline
\end{tabular}

$\mathrm{P} 1=$ at branching stage, $\mathrm{P} 2=$ at pod initiation stage were distributed in main plots and doses of urea spraying, $\mathrm{T} 1=$ application of $100 \%$ recommended fertilizers as basal except urea, $\mathrm{T} 2=$ application of $100 \%$ recommended fertilizers as basal, T3= application of $75 \%$ of urea with $100 \%$ of other fertilizers as basal and rest of the $25 \%$ of urea by spraying, T4= application of $25 \%$ of urea with $100 \%$ of other fertilizers as basal and rest of the $75 \%$ of urea by spraying, T5= application of $50 \%$ of urea with $100 \%$ of other fertilizers as basal and rest of the $50 \%$ of urea by spraying 
Input price: Urea- BDT $16 \mathrm{~kg}^{-1}$, labour: BDT $400 \mathrm{day}^{-1} 08$ hours $^{-1}$, Sprayer- BDT $200 \mathrm{ha}^{-1}$, lentil seed- BDT 100 $\mathrm{kg}^{-1}$ Output price: lentil- BDT $52 \mathrm{~kg}^{-1}$

\section{Discussions}

Yield and yield contributing characters or growth parameters values were increased due to adequate supply of nutrient like nitrogen in proper time incase of basal application of urea with spraying later as in pod initiation stage which is revealed in this present study and this result also similar to (Kuttimani and Velayutham, 2011). (Hossain et al., 2018) reported that maximum grain yield was found when DAP was applied in both branching and pod initiation stages as spray. But in the present study urea was applied only either in branching stage or in pod initiation stage as lentil is a very sensitive to over fertilizer dose and two time spray will increase the production cost ultimately BCR value will be lesser than the recommended method of basal urea application in Bangladesh. In addition incase of two time spray there is a possibility of increasing days to maturity that will destroy the purity of the variety as this variety has released to fit under the fallow period of Aman and Boro rice in Bangladesh. However urea spraying at pod initiation stage with T3 (application of $75 \%$ of urea with $100 \%$ of other fertilizers as basal and rest of the $25 \%$ of urea by spraying) method of fertilizer application gives maximum result in yield and yield contributing character in the present study. Moreover in P2T3 (application of $75 \%$ of urea with $100 \%$ of other fertilizers as basal and rest of the $25 \%$ of urea by spraying) interaction $14 \%$ yield has increased over recommended method of basal urea application. Simlarly (Ram and Punia, 2018) revealed that two time spray is on par with one time spray either in branching or pod initiation stage for seeds/pod which is directly involved in increasing seed yield.

From the above result chapter it is clear that fertilizer management in T3 (application of $75 \%$ of urea with $100 \%$ of other fertilizers as basal and rest of the $25 \%$ of urea by spraying) method along with urea spraying in pod initiation stage significantly increase the yield and growth parameters over no spray or basal application. (Ashour and Thalooth, 1983; El-Karmany et al., 2003; Das and Jana, 2015) reported that 2\% urea spray has positive effect on growth and yield attributes of lentil. Though in the present experiment the doses of urea spraying did not calculated in $(\mathrm{W} / \mathrm{V})$ or in percent basis, rather in weight $(\mathrm{kg} / \mathrm{ha})$ basis but indirectly our doses fits in the @ $2 \%$ urea spray as about 500 litre water is required to spray one hactre of land and $10 \mathrm{~kg}$ of urea was sprayed in T3 (application of $75 \%$ of urea with $100 \%$ of other fertilizers as basal and rest of the $25 \%$ of urea by spraying) treatment at pod initiation stage which showed the best result among the all interactions. Similar result was also found by (Ram and Punia, 2018). They reported that urea spraying by @ 2\% yielded maximum grain which was 25.4 per cent higher over no spray. The reason behind that is additional nitrogen application may delay the senescence of plants then the plants are getting more time to carbon assimilation in the sink parts so that positive effect implies on plant height, pods/plant as well as in seed yield. Delayed maturity also increases the time to store food material into sink.

In correlation analysis it is found that more number of pods/plant facilitate more seeds and thus it can boost seed yield. Similar trend also found by (Nandan and Pandaya, 1980; Rahman and Sarwar, 1982; Balyan and Singh, 1986; Luthra et al., 1990). Plant height also showed positive correlation and it may be as vigourous growth increases the chances of more number of pods/plant, hence it can increase the seed yield also. (Latief et al., 2015) recorded that pods/plant and plant height and biological yield of lentil is directly involved in increasing seed yield so far.

In economic analysis maximum benefit cost ratio was observed in P2T3 (application of 75\% of urea with 100\% of other fertilizers as basal and rest of the $25 \%$ of urea by spraying) interaction. Though in urea spraying treatments total variable cost is higher than no spray but in foliar urea spray there was $14 \%$ yield improvement over no spray which ultimately results in higher BCR over no spray. So urea spray as T3 method of application at pod initiation stage may be beneficial for yield improvement in BARI Masur-9.

\section{Conclusion}

From the above results and discussions it may be concluded that seed yield of BARI Masur-9 may be boosted up by the application of fertilizer like nitrogen containing urea as foliar spray at the later stage of plant growth as pod initiation stage. Fertilizer application in the method of (application of $75 \%$ of urea with $100 \%$ of other fertilizers as basal and rest of the $25 \%$ of urea by spraying at pod initiation stage) gives the maximum result incase of seed yield as well as other yield contributing characters. Correlation coefficient showed that there is positive correlation between seed yield and most of the other yield contributing characters. Economic analysis also reveled that foliar spray of urea as per the above mentioned doses and time gives the highest economic return over other treatment. So application of $75 \%$ of urea with $100 \%$ of other fertilizers as basal and rest of the $25 \%$ of urea by spraying at pod initiation stage may be recommended for yield increasing of BARI Masur-9. 


\section{Acknowledgement}

Regional Agricultural Research Station, Jashore of Bangladesh Agricultural Research Institute has provided the financial support to operate the experiment smoothly. Md. Hafijur Rahman of Regional Agricultural Research Station, Jashore has provided scientific support in the research work and Md. Harun-Or-Rashid of CIMMYT, Bangladesh has enriched the article by writing of it's several parts.

\section{References}

AIS. (2020). Agricultural Information Services of Bangladesh-Krishi Diary 2020 version.

Ashour, N. I., \& Thalooth, A. T. (1983). Effect of soil and foliar application of nitrogen during pod development on the yield of soybean (Glycine max L.) Field Crop Res., 6, 261-266.

Azad, A. K., Wahab, A., Saha, M. G., Nesa, Z., Rahman, M. L., Rahman, H. H., Amin, L. (2019). KrishiProjuktiHatboi (Handbook on Agro-technology), $8^{\text {th }}$ edition. Bangladesh Agricultural Research Institute, Gazipur-1701, Bangladesh, 54. Retrieved from http://www.bari.gov.bd

Balyan, H. S., \& singh, S. (1986). Character association in lentil. Lens., 13(1), 1-3.

BBS (2019). Bangladesh Bureua of Statistics. Yearbook of agricultural statistics-2018, p08. Retrieved from http://bbs.portal.gov.bd/sites/default/files/files/bbs.portal.gov.bd/page/1b1eb817_9325_4354_a756_3d1841 2203e2/Yearbook-2017-Final-05-05-2018.pdf

Das, S. K., \& Jana, K. (2015). Effect of foliar spray of water soluble fertilizer at pre flowering stage on yield of pulses. Agric. Sci. Digest., 35(4), 275-279. https://doi.org/10.18805/asd.v35i4.6858

Davies S. L., Turner N. C., Palta J. A., Siddique K. H. M., \& Plummer J. A. (2000). Australian Journal of Agricultural Research, 51, 855-866.

El- Kramany, M. F., Magda Mohamed, H., \& Nofal, O. A. (2003). Effect of late foliar application with urea and Potasium fertilization on yield, yield components and chemical composition of two mungbean varieties. Egypt J. Appl. Sci., 18, 177-188.

Hamayun, M., Khan, S. A., Khan, A. L., Shinwari, Z. K., Ahmad, N., Kim, Y. H., \& Lee, I. J. (2011). Effect of foliar and soil application of nitrogen, phosphorus and potassium on yield components of lentil. Pakistan Journal of Botany, 43(1), 391-396.

Hossain, M. B., Roy, S., \& Alam, A. B. M. S. (2018). Foliar application of di-ammonium phosphate and triple super phosphate on lentil at drought prone area of banglades. J. Bangladesh Acad. Sci., 42(2), 211-214. https://doi.org/10.3329/jbas.v42i2.40055.

Kobir, M.S., Rashid, M.H., Ahmed, S. (2020). Development of Integrated Fertilizer Management Strategies in Lentil for Higher Productivity in the South-Western Region of Bangladesh. Agricultural science., 2(1), 275281. https://doi.org/10.30560/as.v2n1p275

Kuttimani, R., Velayutham, A. (2011). Foliar application of nutrients and growth regulators on yield and economics of green gram. Madras Agric. J., 98(4), 141- 143.

Latief, A.A.A., Emad, B., Fakher, O., Zakaria, A., Maram, A., \& Mohammad, A. (2015). Genetic Variation for Quantitative Traits in Jordanian Lentil Landraces. Retrieved from https://www.researchgate.net/publication/282730780_Genetic_Variation_For_Quantitative_Traits_In_Jorda nian_Lentil_Landraces

Luthra, S., \& Sharma, P. C. (1990). Correlation and path analysis in lentils (Lens culinaris Med.). Lens Newsletter., 17, 5-8. Retrieved from https://www.researchgate.net/publication/271527382_Correlation_and_path_analysis_in_lentils_Lens_culin aris_Med

Nandan, R., \& Pandaya, B. P. (1980). Correlation, path coefficient and selection indices in lentil. Indian journal of genetics., 40, 399-404.

Rahman, A. R. M. S., \& Sarwar, D. M. (1982). Path coefficient analysis in lentil. Bangladesh journal of Agriculture., 7, 121-127.

Ram, B., \& Punia, S. S. (2018). Effect of seed priming and foliar urea spray on yield and economics in lentil (lens culinaris) under rainfed condition. International Journal of Agriculture Sciences, 10(8), 5801-5803. Retrieved from http://www.bioinfopublication.org/jouarchive.php?opt=\&jouid=BPJ0000217

Salam, M. A., Islam, M. A., Zaman, S. M., Choudhury, R. U., \& Ali, M. O. (2019). Integrated Nutrient 
Management for Lentil; +Mustard Mixed Cropping System. Annual Research Report, Pulses Research Centre, Bangladesh Agricultural Research Institute (2018-2019), 131.

Salisbury, F. B., \& Ross, C. W. (1985). Plant Physiology (3rd ed.). Wadsworth, Belmont, CA. 540 p.

WHO (2020). World Health Organization Timeline - COVID-19. Retrieved June 23, 2020, from https://www.who.int/news-room/detail/27-04-2020-who-timeline---covid-19

Wikipedia. An encyclopedia of Wikimedia foundation. Jessore district (climate). Retrieved June 22, 2020, from https://en.wikipedia.org/wiki/Jessore_District

World bank (2020). The International Bank for Reconstruction and Development (IBRD) andthe International Development Association (IDA), Food Security and COVID-19. Retrieved June 23, 2020, from https://www.worldbank.org/en/topic/agriculture/brief/food-security-and-covid-19

\section{Copyrights}

Copyright for this article is retained by the author(s), with first publication rights granted to the journal.

This is an open-access article distributed under the terms and conditions of the Creative Commons Attribution license (http://creativecommons.org/licenses/by/4.0/). 